\title{
The Mycolic Acids of Mycobacterium chelonei
}

\author{
By D. E. MINNIKIN, ${ }^{1 *}$ S. MEGAN MINNIKIN, ${ }^{1}$ M. GOODFELLOW ${ }^{2}$ \\ AND J. L. STANFORD ${ }^{3}$ \\ ${ }^{1}$ Department of Organic Chemistry, The University, Newcastle upon Tyne NE1 7RU,U.K. \\ ${ }^{2}$ Department of Microbiology, The University, Newcastle upon Tyne NE1 7RU, U.K. \\ ${ }^{3}$ School of Pathology, The Middlesex Hospital Medical School, London WIP 7LD, U.K.
}

(Received 13 May 1981)

\begin{abstract}
Two-dimensional thin-layer chromatography of whole-organism acid methanolysates of Mycobacterium chelonei gives a characteristic pattern of two non-polar mycolic acid methyl esters which allows the organism to be distinguished from all other mycobacteria including Mycobacterium fortuitum. The mycolic acids from Mycobacterium chelonei were composed of approximately equal amounts of a diunsaturated $\alpha$-mycolate and a lower molecular weight $\alpha^{\prime}$-mycolate, though minor amounts of a different $\alpha$-mycolate were also detected. These mycolic acids are the first examples of natural mixtures from mycobacteria lacking major amounts of acids having oxygen functions in addition to the 3-hydroxy acid unit.
\end{abstract}

\section{INTRODUCTION}

High molecular weight 3-hydroxy, 2-alkyl-branched fatty acids, the mycolic acids, are characteristic components of the cell envelopes of all strains of Mycobacterium examined to date (Minnikin \& Goodfellow, 1980). Mycobacterial mycolic acids are homologous compounds having between 60 and 90 carbons, and they usually occur as complex mixtures of so-called $\alpha$-mycolates and acids having oxygen functions $\left(>\mathrm{C}=\mathrm{O},>\mathrm{CH}-\mathrm{OCH}_{3}\right.$, $-\mathrm{COOH}$ ) in addition to the 3-hydroxy acid unit. The carbon skeletons of both oxygenated and $\alpha$-mycolic acids may contain either double bonds or cyclopropane rings and methyl branches. In contrast, mycolic acids from true corynebacteria, nocardiae, rhodococci and related strains have between 20 and 70 carbons, and the only additional functional groups are varying numbers of double bonds (Minnikin \& Goodfellow, 1980). A recently developed procedure, involving thin-layer chromatography of acid methanolysates, has revealed the presence of three characteristic patterns of mycobacterial mycolic acid methyl esters (Minnikin et al., 1980). The mycolates of Mycobacterium tuberculosis, consisting of $\alpha$-mycolates, ketomycolates and methoxymycolates, are an example of the first pattern. The second pattern, exemplified by Mycobacterium avium, comprises a-mycolates, ketomycolates and an $\omega$-carboxymycolate co-occurring with 2 -eicosanol and its homologues. In the third pattern, two characteristic unidentified polar mycolates co-occur with $\alpha$-mycolates in acid methanolysates of Mycobacterium fortuitum and Mycobacterium smegmatis. The present study shows that a fourth pattern is characteristic of acid methanolysates of representatives of Mycobacterium chelonei.

\section{METHODS}

Strains and cultivation. Cultures (Table 1) were maintained on glucose yeast agar (Gordon \& Mihm, 1962) at room temperature. Strains were grown in shake flasks of modified Sauton's medium (Mordarska et al., 1972) for 5 
Table 1. Designation and sources of test strains

Mycobacterium chelonei subsp. abscessus

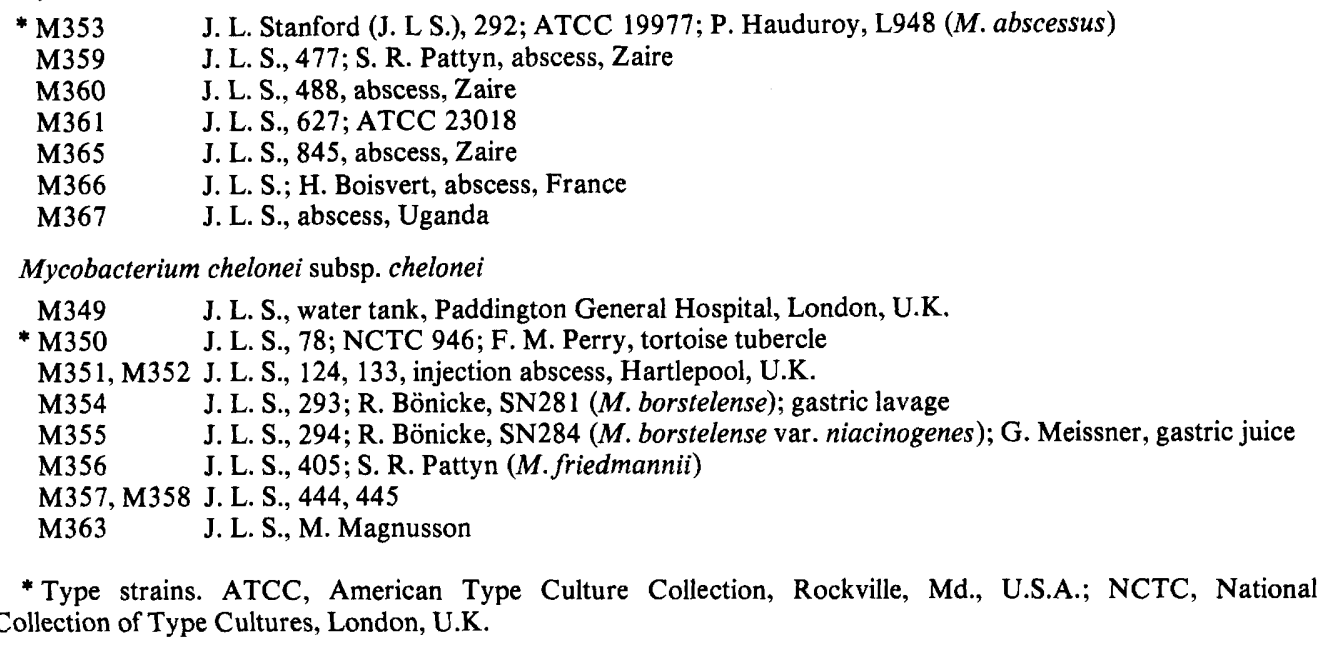

to $7 \mathrm{~d}$ at $30^{\circ} \mathrm{C}$. The organisms were checked for purity at maximum growth, killed with formaldehyde $(1 \%, \mathrm{v} / \mathrm{v})$, harvested by centrifugation, washed with distilled water and freeze-dried.

Mycolic acid analysis. Freeze-dried bacteria $(50 \mathrm{mg})$ were degraded by acid methanolysis, and petroleum ether (b.p. $60-80^{\circ} \mathrm{C}$ ) extracts were examined for long chain components by thin-layer chromatography (t.l.c.) as described previously (Minnikin et al., 1980). Analytical two-dimensional t.l.c. was performed using small plates $(10 \times 10 \mathrm{~cm})$ cut from Merck 5554 silica gel $60 \mathrm{~F}_{254}$ aluminium sheets $(20 \times 20 \mathrm{~cm})$ using a triple development with petroleum ether (b.p. $60-80^{\circ} \mathrm{C}$ )/acetone $(95: 5, \mathrm{v} / \mathrm{v})$ in the first direction followed by a single development in the second direction with toluene/acetone $(97: 3, \mathrm{v} / \mathrm{v})$ (Minnikin et al., 1980). The positions of separated components were revealed by spraying with a $10 \%$ ethanolic solution of molybdophosphoric acid followed by heating at $120^{\circ} \mathrm{C}$ for $15 \mathrm{~min}$. Individual mycolic acid methyl esters were isolated from strains M350, M354, M365 and M366 by preparative t.l.c. on layers $(1 \mathrm{~mm})$ of Merck 7748 silica gel PF $_{254+366}$, separated bands being detected with ultraviolet light $(366 \mathrm{~nm})$.

Mass spectra of mycolic acid methyl esters were taken on an AEI MS9 instrument using a direct insertion probe, an ionizing voltage of $70 \mathrm{eV}$ and a temperature range of 190 to $220^{\circ} \mathrm{C}$. Nuclear magnetic resonance (n.m.r.) proton spectra $(220 \mathrm{MHz})$ were recorded for deuterochloroform solutions by the Physico-Chemical Measurements Unit, Harwell.

\section{RESULTS}

Two-dimensional thin-layer chromatography of whole-organism acid methanolysates gave, in all cases, a simple pattern of three major long-chain components as exemplified by the pattern for M. chelonei M350 (Fig. 1); copies of the patterns for all other species examined have been deposited with the British Library Lending Division, Boston Spa, Yorkshire LS23 7BQ, as Supplementary Publication No. SUP 28011 (3 pages). (Copies may be obtained from the BLLD on demand; where possible, requests should be accompanied by prepaid coupons, held by many university and technical libraries and by the British Council.) The most mobile component corresponded to non-hydroxylated fatty acid methyl esters and the other two components had the chromatographic properties of mycolic acid methyl esters (Fig. 1). The relative proportions of the two mycolates appeared to be quite constant in the strains studied.

The mass spectra of both mycolic acid methyl esters from strains M350, M354, M365 and M366 all contained peaks at $m / e 382$ corresponding to pyrolytic release in the mass spectrometer (Etémadi, 1967a) of methyl tetracosanoate. The spectra of the more polar mycolates from these strains were all very similar and contained peaks at $m / e 546$ and 574 


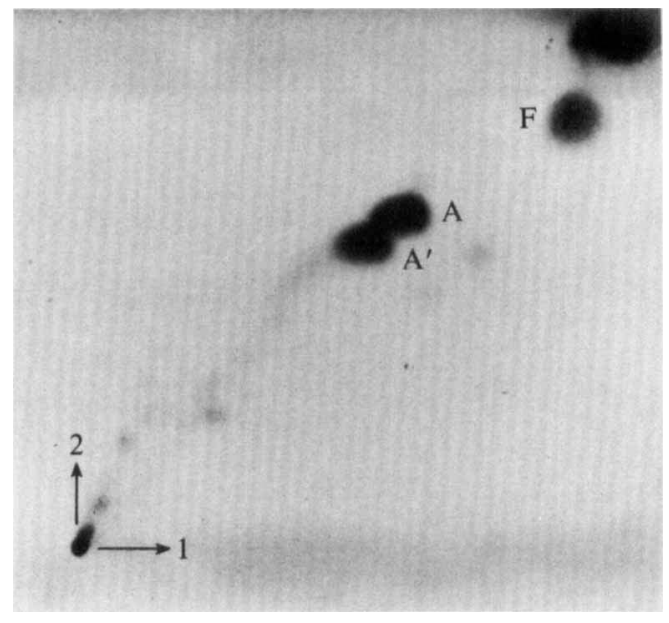

Fig. 1. Two-dimensional t.l.c. of whole-organism acid methanolysate of $M$. chelonei M350. A triple development with petroleum ether (b.p. $\left.60-80^{\circ} \mathrm{C}\right) /$ acetone $(95: 5, \mathrm{v} / \mathrm{v})$ was used in the first direction followed by a single development with toluene/acetone $(97: 3, v / v)$ in the second direction. Abbreviations: F, non-hydroxylated fatty acid methyl esters; $A, \alpha$-mycolate; $\mathrm{A}^{\prime}, \alpha^{\prime}$-mycolate.

(main components in italics) corresponding to monounsaturated meroaldehydes having 38 and 40 carbons produced by the pyrolytic decomposition noted above. Complementary pairs of peaks corresponding to anhydromycolates having 62 and 64 carbons were observed at $\mathrm{m} / \mathrm{e}$ 910 and 938.

The less polar mycolates from the four strains under study gave more complex mass spectra. Peaks due to anhydromycolates were not consistently recorded but homologous series of meroaldehyde fragments were readily identified. Peaks of the predominant series were found at $m / e 698,726,754,782$ and 810 corresponding to diunsaturated meroaldehydes having $49,51,53,55$ and 57 carbons; peaks of the minor series were found at $m / e 684,712,740,768$ and 796 corresponding to diunsaturated meroaldehydes with 48,50 , 52,54 and 56 carbons. For the latter minor series the main component in all cases was that at $m / e$ 768; for the main series $m / e 782$ was the principal component for strain M365 but in the other three strains $m / e 754$ was the largest peak in this series. Taking together the data for these two series of meroaldehyde fragments and the size of the chain in the 2-position, the least polar mycolates from these strains appear to comprise a minor series having even numbers of carbon atoms $\left(\mathrm{C}_{72}\right.$ to $\left.\mathrm{C}_{80}\right)$ and a major series with odd numbers of carbon atoms $\left(\mathrm{C}_{73}\right.$ to $\left.\mathrm{C}_{81}\right)$.

Larger amounts of mycolic acid methyl esters were isolated by preparative t.l.c. of the methanolysate from $1300 \mathrm{mg}$ of $M$. chelonei M354 to give $25 \mathrm{mg}$ of the least polar mycolate and $15 \mathrm{mg}$ of the more polar ester (Fig. 1). Examination of both mycolic esters by $220 \mathrm{MHz}$ proton n.m.r. showed the presence of resonances characteristic of the 2-branched, 3-hydroxy methyl ester unit and two terminal methyl groups (Etemadi, $1967 \mathrm{~b}$; Minnikin \& Polgar, 1966). The more polar mycolate contained a clear triplet $(2 \mathrm{H})$ at $\delta 5.38$ characteristic of a cis double bond (Frost \& Gunstone, 1975) but for the least polar mycolate a similar triplet at $\delta 5.38(2 \mathrm{H})$ was accompanied by a multiplet $(2 \mathrm{H})$ at $\delta 5 \cdot 32$. The spectrum of the least polar mycolate also contained a doublet $(3 \mathrm{H})$ at $\delta 0.95$ corresponding to a methyl group on a carbon adjacent to a double bond (Etémadi et al., 1967). Signals characteristic of cyclopropane rings (Minnikin, 1966; Longone \& Miller, 1967) were not found in the n.m.r. spectra of either of these mycolic esters.

The experimental data lead to the conclusion that the least polar mycolates from $M$. chelonei (Fig. 1) are the so-called $\alpha$-mycolates (Etémadi, $1967 b)$. The principal series $\left(C_{73}\right.$ to 


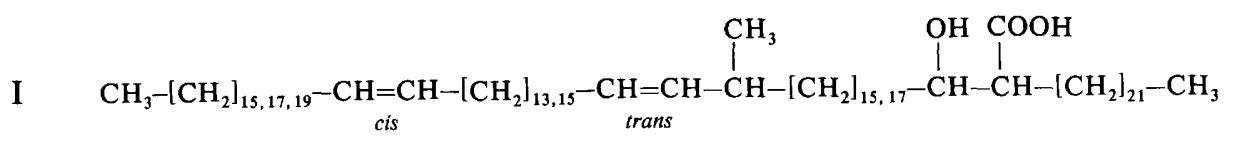

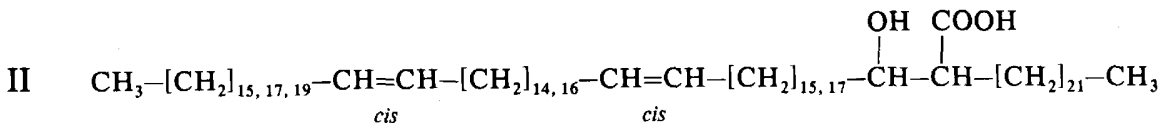

III

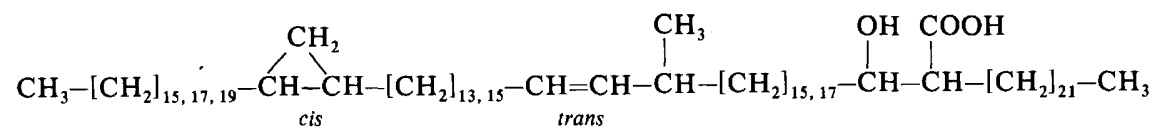

IV $\mathrm{CH}_{3}-\left[\mathrm{CH}_{2}\right]_{15,17}-\mathrm{CH}=\mathrm{CH}-\left[\mathrm{CH}_{2}\right]_{17,19} \stackrel{\mathrm{CH}}{\mathrm{C}}-\stackrel{\mathrm{C}}{\mathrm{C}}-\left[\mathrm{CH}_{2}\right]_{21}-\mathrm{CH}_{3}$

$\left.\mathrm{C}_{81}\right)$ appears to correspond closely to the methyl-branched mycolates $\left(\mathrm{C}_{75}\right.$ to $\left.\mathrm{C}_{83}\right)$ having the structure (I), characterized previously from Mycobacterium smegmatis (Etémadi, $1967 b$; Etémadi et al., 1967; Wong et al., 1979). The composition of the minor series $\left(C_{72}\right.$ to $\left.C_{80}\right)$ of $\alpha$-mycolates cannot be assigned with similar confidence but it is considered more likely that they are similar to the di-cis-alkenic acids $\left(\mathrm{C}_{74}\right.$ to $\left.\mathrm{C}_{82}\right)$ (II) rather than to cyclopropyl mycolic acids $\left(\mathrm{C}_{76}\right.$ to $\left.\mathrm{C}_{84}\right)$ (III), both isolated previously from $M$. smegmatis (Etemadi, $1967 \mathrm{~b}$; Etémadi et al., 1967). The most polar mycolates from strains of $M$. chelonei (Fig. 1) correspond very closely to the so-called monounsaturated $\alpha^{\prime}$-mycolates also previously characterized from $M$. smegmatis (Krembel \& Etémadi, 1966; Etémadi, 1967b; Wong \& Gray, 1979). The mass spectrometric data summarized above indicate the structure (IV) for the $\alpha^{\prime}$-mycolates of $M$. chelonei.

\section{DISCUSSION}

The mycolic acids from $M$. chelonei strains consist of approximately equal amounts of a diunsaturated $\alpha$-mycolate (I) and a lower molecular weight $\alpha^{\prime}$-mycolate (IV); minor amounts of a different $\alpha$-mycolate (II) were also detected. Mycolic acids having the same structural types have been characterized previously from Mycobacterium smegmatis (Krembel \& Etémadi, 1966; Etémadi, 1967 b; Etémadi et al., 1967; Wong et al., 1979; Wong \& Gray, 1979). In the case of $M$. smegmatis, however, the $\alpha^{\prime}$-mycolates are usually minor components, though oxygenated, so far uncharacterized, mycolates are also encountered (Minnikin et al., 1980). The mycolic acids of $M$. chelonei are the first examples of natural mixtures from mycobacteria lacking major amounts of acids having oxygen functions in addition to the 3-hydroxy acid unit.

Mycobacterium chelonei was established by Bergey et al. (1923) to accommodate Friedmann's (1903) turtle tubercle bacillus. Stanford \& Beck (1969) found strains of Mycobacterium abscessus (Moore \& Frerichs, 1953), Mycobacterium borstelense (Bönicke \& Stottmeier, 1965) and Mycobacterium runyonii (Bojalil et al., 1962) to be similar to the turtle tubercle bacillus and proposed that all three taxa be reduced to synonyms of $M$. chelonei. Subsequently, Stanford et al. (1972) recognized two geographical subgroups of $M$. chelonei and these were later given subspecific rank as $M$. chelonei subsp. chelonei and $M$. 
chelonei subsp. abscessus (Kubica et al., 1972). Strains of the two subspecies can be distinguished by a number of biochemical and physiological properties (Stanford et al., 1972; Runyon et al., 1974) but not on the basis of lipid analysis (Jenkins et al., 1971). The present finding that good representatives of the two subspecies contain the same types of mycolic acids is further evidence of the integrity of $M$. chelonei.

Mycobacterium chelonei and Mycobacterium fortuitum are rather similar and contain strains able to cause abscesses and pulmonary disease in man (Pattyn \& Portaels, 1972). Strains of the two species can be distinguished by biochemical and colonial properties (Pattyn et al., 1974), bacteriocin typing (Takeya \& Tokiwa, 1972), in vitro antibiotic sensitivity studies (Haas et al., 1973), polyacrylamide gel electrophoresis of cell proteins (Haas et al., 1974) and immunodiffusion studies (Kubica et al., 1972; Stanford et al., 1972; Pattyn et al., 1974) but there is still a need for a simple reliable method to distinguish between them. Thin-layer chromatography of whole-organisms methanolysates provides an easy and accurate way of distinguishing $M$. chelonei from $M$. fortuitum and all other mycobacteria.

Thanks are due to P. Kelly and S. H. Addison for mass spectra and to Judith M. Best and Carole Todd for technical assistance. D. E. M. and M. G. are indebted to the Medical Research Council (G974/522/S) and Science Research Council (GRA 88651); the S.R.C. also financed the $220 \mathrm{MHz}$ proton n.m.r. spectral analysis.

\section{REFERENCES}

Bergey, D. H., Harrison, F. C., Breed, R. S., Hammer, B. W. \& Huntoon, F. M. (1923). Bergey's Manual of Determinative Bacteriology, 1st edn. Baltimore: Williams \& Wilkins.

Bojalil, L. F., CÉrbon, J. \& Trujillo, A. (1962). Adansonian classification of mycobacteria. Journal of General Microbiology 28, 333-346.

BÖNICKE, R. \& STOTTMEIER, J. L. (1965). Erkennung und Identifizierung von Stämmen der Species Mycobacterium borstelense. Beiträge zur Klinik und Erforschung der Tuberkulose und Lungenkrankheiten 130, 210-222.

ETÉMADI, A.-H. (1967a). The use of pyrolysis gas chromatography and mass spectroscopy in the study of the structure of mycolic acids. Journal of Gas Chromatography 5, 447-456.

EtÉmADI, A.-H. $(1967 b)$. Les acides mycoliques: structure, biogenèse et intérêt phylogénétique. Exposés annuels de biochimie médicale 28, 77-109.

Etémadi, A.-H., Pinte, F. \& Markovits, J. (1967). Nouvelle analyse des acides $\alpha$-mycoliques de $\mathrm{Myco}$ bacterium smegmatis. Bulletin de la Société chimique de France, 195-199.

FriedmanN, F. F. (1903). Der Schildkröten-Tuberkelbacillus, seine Züchtung, Biologie und Pathogenität. Zentralblatt für Bakteriologie, Parasitenkunde, Infektionskrankheiten und Hygiene ( $A B$ teilung I, Originale) 34, 647-658.

Frost, D. J. \& Gunstone, F. D. (1975). The PMR analysis of non-conjugated alkenoic and alkynoic acids and esters. Chemistry and Physics of Lipids 15, 53-85.

GorDON, R. E. \& MIHM, J. M. (1962). Identification of Nocardia caviae (Erikson) nov.comb. Annals of the New York Academy of Sciences 98, 628-636.

HAAS, H., Michel, J. \& SACHS, T. (1973). In vitro susceptibility of Mycobacterium fortuitum and related strains to cephalosporins. Journal of Medical Microbiology 6, 141-145.
HaAs, H., Michel, J. \& Sachs, T. (1974). Identification of Mycobacterium fortuitum, Mycobacterium abscessus, and Mycobacterium borstelense by polyacrylamide gel electrophoresis of their cell proteins. International Journal of Systematic Bacteriology 24, 366-369.

Jenkins, P. A., MARKs, J. \& Schaefer, W. B. (1971). Lipid chromatography and seroagglutination in the classification of rapidly growing mycobacteria. American Review of Respiratory Disease 103, 179187.

Krembel, J. \& EtÉmadi, A.-H. (1966). Sur la structure d'un nouveau type d'acides mycoliques de Mycobacterium smegmatis. Tetrahedron 22, 11131119.

Kubica, G. P., Baess, I., Gordon, R. E., Jenkins, P. A., KWAPINSKI, J. B. G., MCDURmont, C., Pattyn, S. R., Saito, H., Silcox, V., Stanford, J. L., TAkeya, K. \& Tsukamura, M. (1972). A cooperative numerical analysis of the rapidly growing mycobacteria. Journal of General Microbiology 73, 55-70.

Longone, D. T. \& Miller, A. H. (1967). Shielding effects in substituted cyclopropanes. Chemical Communications, 447-448.

MinNIKIN, D. E. (1966). Nuclear magnetic resonance spectra of long-chain 1,2-disubstituted cyclopropane esters. Chemistry and Industry, 2167.

MinNikIN, D. E. \& Goodfellow, M. (1980). Lipid composition in the classification and identification of acid-fast bacteria. In Microbiological Classification and Identification, pp. 189-256. Edited by $M$. Goodfellow \& R. G. Board. London: Academic Press.

Minnikin, D. E. \& Polgar, N. (1966). Studies on the mycolic acids from human tubercle bacilli. Tetrahedron Letters, 2643-2647.

Minnikin, D. E., Hutchinson, I. G., CaldicotT, A. B. \& Goodfellow, M. (1980). Thin-layer 
chromatography of methanolysates of mycolic acid-containing bacteria. Journal of Chromatography 188, 221-233.

MoOre, M. \& Frerichs, J. B. (1953). An unusual acid-fast infection of the knee with subcutaneous abscess-like lesions of the gluteal region. Journal of Investigative Dermatology 20, 133-169.

MoRdARSKA, H., MoRdarski, M. \& Goodfellow, M. (1972). Chemotaxonomic characters and classification of some nocardioform bacteria. Journal of General Microbiology 71, 77-86.

Pattyn, S. R. \& PoRtaels, F. (1972). Identification and clinical significance of mycobacteria. Zentralblatt für Bakteriologie, Parasitenkunde, Infektionskrankheiten und Hygiene (Abteilung I, Originale) 219, 114-140.

Pattyn, S. R., Magnusson, M., Stanford, J. L. \& Grange, J. M. (1974). A study of Mycobacterium fortuitum (ranae). Journal of Medical Microbiology 7, 67-76.

Runyon, E. H., Wayne, L. G. \& Kubica, G. P. (1974). Family II. Mycobacteriaceae Chester 1897, 63. In Bergey's Manual of Determinative Bac- teriology, 8th edn, pp. 681-701. Edited by R. E. Buchanan \& N. E. Gibbons. Baltimore: Williams \& Wilkins.

StANFORD, J. L. \& BeCK, A. (1969). Bacteriological and serological studies of fast growing mycobacteria identified as Mycobacterium friedmannii. Jour nal of General Microbiology 58, 99-106.

Stanford, J. L., Gunthorpe, W. J., PATtyn, S. R. \& Portaels, F. (1972). Studies on Mycobacterium chelonei. Journal of Medical Microbiology 5, 171182.

TAKEYA, K. \& ToKIWA, H. (1972). Mycobacteriocin classification of rapidly growing mycobacteria. International Journal of Systematic Bacteriology 22, 178-180.

WONG, M. Y. H. \& GRAY, G. R. (1979). Structures of the homologous series of monoalkene mycolic acids from Mycobacterium smegmatis. Journal of Biological Chemistry 254, 5741-5744.

Wong, M. Y. H., STECK, P. A. \& GRAY, G. R. (1979). The major mycolic acids of Mycobacterium smegmatis. Journal of Biological Chemistry 254, 57345740. 